\title{
FROM INSTITUTIONALISATION \\ TO (DE)INSTITUTIONALISATION - TRANSFERRING ISOLATION PRACTICES FROM NURSING HOME CARE TO SUPPORTED HOUSING IN POLAND
}

\begin{abstract}
During the COVID-19 pandemic, discussion re-emerged in many places, among them Poland, about how institutions that provide nursing home care (NHC) contribute to the social isolation of their residents; deinstitutionalisation (DI) as an alternative to collective forms of housing, in the form of sheltered housing and assisted housing, was brought to the fore.

The aim of the research was to analyse these forms of housing in terms of the way deinstitutionalisation is perceived and understood by the creators of protected and assisted housing for people with disabilities.

The applied perspective is the concept of the permeability of an institution, placed on a continuum between "permeable" and "total". The research also employed a critical discourse analysis, which included 20 statutes concerning protected and assisted housing.

The results of the analysis indicate that there is a practice of transferring elements of institutional thinking and limiting human rights to those forms of housing that are intended to be an introduction to (or an implementation of) the idea of DI. The concepts of sheltered and assisted housing still include many features that may be identified with "total" institutions on the permeability continuum.
\end{abstract}

Keywords: permeable institution, total institution, deinstitutionalisation, supported housing, sheltered housing, nursing home care, disability

Dr, Faculty of Economics and Sociology; e-mail: zbigniew.glab@uni.lodz.pl; https://orcid.org/0000-0003-2017-0915 


\section{INTRODUCTION}

Although nursing home care (NHC) providers were already perceived as total institutions, their complete closure and isolation from the world (with both exit bans and visiting bans) during the COVID-19 pandemic emphasised this character further, transforming them into total institutions, in Goffman's understanding of the term. At the same time, in addition to numerous proposals intended to strengthen the material and human resources of the NHC providers in Poland, there were appeals to fully deinstitutionalise social services under the UN Convention on the Rights of Persons with Disabilities (CRPD), in order to remedy the isolation of residents. This was related not only to the existing pandemic but also the nature of these institutions [Jagura 2020: 4; Organisations 2020; Strategy 2020: 70].

The deinstitutionalisation (DI) of services should be understood as the transition from institutional care to services provided in the local community, which ultimately leads to the elimination of social isolation for groups who live in difficult circumstances, such as the elderly, people with disabilities, people in foster care, or people in a homelessness crisis [Guidelines 2019: 6]. The term "institution" here refers to its sociological dimension, described as patterns of social behaviour. Various definitions of "institution" phrase it as a set of beliefs and procedures established by a community, a habit of thinking, or norms that regulate the relations between individuals [Sadowski 2014: 92-93]. The complexity of human relationships and behaviours leads to a need for them to be culturally and normatively regulated. Based on those regulations, various social establishments arise (such as buildings, places, or rooms [cf. Goffman 1991: 15]). Among them are facilities dedicated to solving particular problems - and where people in need live [cf. Mayr 2015: 757]. DI does not entail merely eliminating facilities; it involves a change of institutional arrangements based on modified social policy rules. The term "institution" is not negative in itself, and DI also involves institutional settings as a form of re-institutionalisation.

Deinstitutionalisation is advanced in Scandinavia, the UK, North America, and Australia [Šiška and Beadle-Brown 2011: 125], and began much later in post-communist Central and Eastern Europe. Poland is one of the last countries (following Bosnia and Herzegovina, Bulgaria, Croatia, the Czech Republic, Estonia, Hungary, Latvia, Lithuania, North Macedonia, Romania, Serbia, and Slovakia) to prepare to develop laws and policies to dismantle residential institutions [cf. Maldenov and Petri 2019: 2]. That said, certain actions have been carried out for at least a decade in Poland concerning DI, and the Polish experience may be valuable to other policymakers, social partners, and researchers in Europe. 
In the presented research, consideration was given to one of the DI instruments implemented in Poland, namely "sheltered-supported" (created under Act of Social Welfare) [Act 2004: Art. 53] and assisted housing ${ }^{1}$ (created by social forces), which is intended to prevent people from reaching institutions and allows (some) individuals to leave the institution and become independent. Thus, an opposing pair emerges here: $\mathrm{NHC}$ - sheltered/supported housing, where the latter deconstructs institutional care, defined as factors such as the number of inhabitants, the lack of individualised services, organisational requirements being prioritised over the residents' individual needs, residents' lack of sufficient control over their lives and decisions, isolation from the general community, and the need to live with others [cf. Guidelines 2019: 8].

The research aimed to ascertain how institutions that run sheltered or assisted housing perceive the assumptions of DI and the related human rights proposals (including the idea of independent living by people with disabilities, derived from the CRPD). The main research hypothesis is as follows: certain institutional forms are implement in the operating principles of sheltered/supported housing, which may indicate tendencies to limit the autonomy of residents and contribute to their social isolation.

Sheltered/supported housing is aimed at many groups; however, this study concerns people with disabilities as one group of residents that live in NHC sites. Other groups, and especially elderly people, do not always have needs and goals that coincide with those proposed by people with disabilities, and they are not involved in emancipatory activities within the scope of the CRPD.

\section{THEORETICAL FRAMEWORK}

The theoretical framework of this study is determined by the concept of the "permeability" of institutions, where at one end of the continuum, there is a permeable institution, and at the other end, a total institution. The term "permeable institution" was introduced by Quirk, Lelliott, and Seale [2006: 2106-2107] as an improved and more nuanced description of life in psychiatric institutions,

1 The nomenclature in Polish is complex. The Act [2004] uses the phrase "chronione wspierane", which can be translated as "sheltered supported" (in short: "sheltered"). Housing that is not covered by the Act is called "wspomagane", which can also be translated as "supported". To distinguish between the two forms, housing not covered by the Act is translated as "supported housing". The "sheltered/supported" form was used in the article for the collective description of both types of housing. 
compared to the so-called "brick and mortar" narration of Goffman's total institution concept, which is becoming outdated in the field of medical institutions, due to the DI process. It is worth recalling that Goffman [1991: 111-114] also uses the terms "permeability - impermeability" to describe a variety of total institutions, with an emphasis on the latter category. Quirk, Lelliott, and Clive conducted their research nearly forty years after Goffman and found that medical institutions function at a different evolutionary level, causing them to formulate the conceptual continuum of institutional permeability.

Extreme values on the continuum can be described dichotomously, showing potential contrasts between a permeable institution and a total institution in categories such as length of stay (short - long), location (in the community - isolated), communication with the outside world (open - controlled), the openness of the institution (voluntary exits and entries - closed), control (transparency of the organisation through audits and the media - the world of institutions invisible from the outside), social structure (blurred lines of division - strict hierarchy), institution culture (polluted by external culture and allowing the previous identity of the individual to be kept - values and life institutions as superior, perceived in terms of an individual's position in the hierarchy), and staff-resident relations (consent, informality, the possibility of residents having a voice - paternalism, formalisation, residents' refusal to speak) [Quirk, Lelliott, Seale 2006: 2109-15].

The starting point for the research was the matter of placing NHC providers and sheltered/supported housing on the aforementioned continuum. The restrictions introduced during the COVID-19 pandemic, which allowed for the complete isolation of NHC providers from the world, achieved Goffman's "closed-door" symbolism: a physical barrier, set by a total institution (in his typology, Goffman mentions nursing homes among the institutions intended for the care of people who are incapable and harmless at the same time [Goffman 1991: 16]). In non-pandemic conditions, NHC functions as a type of institution which may take over the life of an individual to a large extent.

Among the Polish studies that take the above-described perspective regarding NHC providers, one may mention Tarkowska [1997], Zbyrad [2012], Niedbalski [2013], and Kurowski [2014]. For the purposes of the present study, and on the basis of the analyses by these researchers, the following catalogue of features has been prepared; it indicates the functions of NHC in terms of a "total" institution: (a) activities in the inhabitants' lives are mostly in the same place; (b) the inhabitants' lives are governed by the one and the same authority; (c) members of the group are treated equally and must perform the same activities; (d) the whole day is planned in advance, and a team of supervisors oversees it; (e) various activities 
are compulsory and form part of a single master plan; (f) there is interference with the intimate sphere of an individual's life, a lack of privacy, control over residents; (g) taking responsibility for charges; (h) a relationship of professional staff - residents; (i) asymmetrical relationships between staff and charges, the strong position of staff; (j) mediation by staff between the charges and the outside world; (k) monitoring relations among residents; (l) the ability for staff to move residents to other rooms, rationing space; $(\mathrm{m})$ strict formal regulations.

At this point, it is worth returning to Goffman and noting that in his concept, a total institution need not be purely negative in its connotations, though its functions are based on a certain regime (e.g., orders or barracks), and its total character may result - at least partially - from care for an individual, as is the case with NHC. For some individuals, a total institution may become a refuge that ensures safety, peace, and protection against the oppression of their own family, social environment, or the state [Posłuszny 2017: 125]. However, it should be noted that the main reasons for placing people with disabilities into NHC institutions often include difficult material and personal circumstances. As a result, the inhabitants do not usually have a way out of the NHC, and it accordingly becomes an isolated micro-social structure for them [Niedbalski 2013: 50].

When attempting to organise and update the concept of a total institution, Posłuszny [2017: 136] draws attention to two basic conditions that should be met: a bureaucratic structure (which translates into the goals of the institution and the methods of achieving them in the form of written and unwritten rules) and the subordination of a given person to the institution for the majority of the time (whether physically within it, or under delegated supervision). The essence here is, therefore, not the place itself (although it may play an important role) but a certain formal organisation and structure. The length of time that the total institution controls (or determines the lifestyle of) an individual is also of significance. Posłuszny [2017: 137] proposes setting an agreed quantitative limit at 50\%. Exceeding this value means that the individual does not spend the majority of his/her time alone.

Although it is easy to describe NHC sites in terms of total institutions, one should avoid exaggerated literality, as they do not have all of the features of a model total institution; similarly, creating the image of an "average resident" may lead to misunderstandings [cf. Posłuszny 2017: 128]. Instead, one might say that NHC providers have shifted on the continuum of permeability towards total institutions. However, residents are not completely deprived of control, and many of them leave the facility freely (although at certain times, and their exits must be reported) for the duration of their classes or to satisfy their life 
needs [cf. Niedbalski 2013: 58]. It is possible to imagine situations where not only individual facilities may have different degrees of permeability, but also people in the same institution may perceive particular routines subjectively and have different attitudes and expectations of the institution. For example, in the same facility, there may reside a mobile person who takes care of his/her affairs outside of the NHC site, a bed-ridden person whose life is often confined to one room, and a person with an intellectual disability who is especially "guided" by the staff. The worlds of these people, their reasons for going into the facility, and their perceptions of the institution can differ greatly.

An alternative to NHC is sheltered/supported housing, which should be understood as a tool in the DI process. By definition, it should gravitate towards the other end of the permeability continuum. This type corresponds with the provisions of the CRPD, particularly those from Article 19 about the independent living of people with disabilities, who should "have the opportunity to choose their place of residence and where and with whom they live on an equal basis with others and are not obliged to live in a particular living arrangement" [CRPD 2006, Art. 19a].

The General Commentary to Article 19 [CRPD 2017, p.16c] indicates an individual's autonomy and the possibility of making a choice as the basic determinants of independent living, while also criticising all forms of housing that violate those principles. In the Polish DI executive practice, it was assumed that the most appropriate way would be to create sheltered/supported housing [MRiF 2016: 6-7].

The definition of sheltered housing is included in Art. 53 of the Act on Social Welfare [Act 2004]. People with disabilities (including mental problems) and elderly people (including the chronically ill) - who are potentially the most frequent clients of $\mathrm{NHC}$ - are emphasised here. Housing is intended for people who do not require round-the-clock care, and it is used to prepare residents for independent living or to support them in their daily functions. Housing can take the form of training (temporary, self-empowering) or sheltered (temporary or permanent housing). This trend is also included in assisted housing, which operates on similar principles without being authorised by the Act. In each case, housing should be "an alternative to staying in a facility that provides round-the-clock care" [Guidelines 2019: 7-8; cf. Strategy 2020: 70].

The Polish Strategy for People with Disabilities [2020: 70] calls for the legal standardisation of sheltered and assisted housing as a service that is part of DI. However, as some researchers have pointed out, the independence emphasised during this service relates to the functional sphere (support in specific activities), 
and not always to independent living in a place where several people did not know each other before living together (living alone is not guaranteed).

In such a situation, the idea of sheltered/supported housing does not fully correspond to the assumptions of DI, by not allowing for independent living and by using collective forms of residence, even if they include small numbers of people. From this perspective, these forms of housing constitute an introduction to DI [Marciniak-Madejska, Stenka, Weiner n.d.: 25-26]. However, regardless of the conditions that result from the strong institutionalisation of disability in Poland, both sheltered and assisted housing may be treated as being oriented towards DI, and they should thus be potentially closer to permeable institutions on the continuum.

\section{RESEARCH MATERIAL}

Twenty regulations concerning sheltered and assisted housing were analysed. The query was based on the results of a Google search" of the phrases "regulamin mieszkania chronionego wspieranego" 3 and "regulamin mieszkania wspomaganego". ${ }^{4}$

The initial procedure was to select the ten highest-ranked results from each of the sheltered and assisted housing categories. However, it turned out that there are not many assisted housing regulations available (7), which is why 13 from sheltered housing were selected to obtain the overall number. This proportion may reflect the ratio of the number of sheltered units (which is currently 1,355 according to the Strategy [2021: 65]) and the ratio of assisted units; the exact number of the latter type is unknown but may be estimated at several hundred.

The regulations mostly come from urban ${ }^{5}$ areas (15), but some are in rural areas (5) throughout Poland and are run by local authorities through the agency of social welfare centres (13), a district family support centre (1), non-governmental organisations (3), or in a partnership between municipal authorities and nongovernmental organisations (3). The locations are evenly distributed from north to south and from east to west, with the exception of the north-eastern part of the country, where no regulations were found.

\footnotetext{
2 To avoid the "personal information bubble problem", all of the browser's cookies were deleted and user location detection was disabled.

3 "Regulation for sheltered supported housing".

4 "Regulation for supported housing".

5 Medium and small cities.
} 
The regulations of assisted housing do not differ qualitatively from those of sheltered housing, and in many cases, they contain the same solutions (also, literally, the same provisions). ${ }^{6}$ The regulations average 3-9 pages of standard text.

As the focus of the study was on the regulations of potentially permanent housing for people with disabilities, the regulations of housing intended for groups other than those with disabilities and training facilities were rejected.

\section{THE METHOD}

The study adopted critical discourse analysis (CDA) as a perspective (and method) of analysing social problems to indicate how power relations (including abuses of power), as well as domination and inequalities, are introduced and reproduced. This is also related to the perception of discourse as an ideological form of action [cf. van Dijk 2001: 352-353; Fairclough 2012: 9]. Ideological-discursive formations have the capacity to dominate "as 'ideological/discoursal power' which exists alongside economic and political power, and can normally be expected to be held in conjunction with them" [Fairclough 1995: 41]. Thus, the CDA is "a category for designating particular ways of representing particular aspects of social life", and analysing it gives the chance to articulate problems of social exclusion [Fairclough 2005: 77].

The analysis refers to the "school" of CDA [cf. Wodak and Meyer 2009: 5] that assumes the researcher's involvement, both in the scientific process and in generating social change through solidarity with the dominated groups [cf. van Dijk 2001: 352-353; Fairclough 2012: 10]. By extension, research is a kind of intervention that benefits disadvantaged groups [cf. Fairclough 1992/2006: 9] and is a form of analysis "with attitude" [van Dijk 2001: 96].

In the presented study, such involvement is associated with adopting the critical disability studies (CDS) perspective, and within it, the concept of independent living that is derived from the CRPD and promoted by the emancipatory circles of persons with disabilities. One of the crucial assumptions of CDS is that research should be perceived as more than an "academic exercise" and as an expression of political commitment [Goodley 2017: 191-192]. In other words, referring to the critical theory, research should prove its value but also be "an essential element in the historical effort to create a word which satisfies the needs and powers of

6 Subsequent analysis of the material showed that the institutions that run both types of housing assume that specific individuals will stay there for a while, which in practice equates these forms of housing with the training type. 
man" [Horkheimer 1972/2002: 246]. To that end, the author of the present study delineates his own role as an ally of people with disabilities in their emancipatory quest for social justice, which arises from activism [cf. Wodak, Meyer 2009: 7; Grue 2011: 532].

Social reality is mediated and reflexive; the way it is presented, interpreted, and conceptualised is also part of this experience. It has a "material - semiotic" character, combining material aspects of social reality with semiotic (in this case, linguistic) aspects. This is related to a transdisciplinary approach that requires dialogue between different research disciplines [Wodak, Meyer 2009: 2; Fairclough 2012: 9; cf. Czyżewski et al. 2017: 10-11]. In this case, apart from the linguistic and sociological analysis, the forms of analysis in the field of public policies should be indicated.

CDA is useful for the study of legal provisions (which regulations are a form of) "in terms of the discriminatory structures reproduced in them" and "images of certain types of people and phenomena" [Sulikowski 2014: 110], as well as the "control" category (which is related to power) [van Dijk 2001: 354]. An established law may consider the self-protective practices of an institution above all, relegating an individual's freedom or safety to the background [Sulikowski 2014: 110]. In the discussed context, this may mean the desire to secure the interests of the institution (as the provider of sheltered/supported housing) in matters related to liability for residents, which may manifest itself in the form of control and restrictions of individual freedom.

Fairclough offers three ways to understand the concept of discourse: (a) it creates meanings in the social process, (b) it is the language associated with a specific social field or practice, or (c) it is a way of constructing aspects of the world associated with a specific perspective [Fairclough 2012: 11]. In the presented study, the last variant was adopted, with an institutional perspective; this should be understood as the way sheltered/supported housing is perceived by the institutions running it in relation to the permeability continuum.

The research process was divided into four phases: (I) focusing on "social wrong" and its semiotic aspects, (II) identifying obstacles to preventing harm, (III) reflecting on whether the social order "requires" harm, and (IV) identifying possible ways of avoiding obstacles [Fairclough 2012: 13].

Phase I focused on the qualitative analysis of the content of the text of the regulations ["items" - cf. Czyżewski 2008: 24], which may indicate features of sheltered/supported housing that potentially refer to how NHC providers function, thereby indicating their institutional character. The study searched for such "objects" whose operationalisation may have a significant impact on the way the 
life of an individual is organised [Fairclough 2012: 10;12] by dint of an institution's power, demonstrated in practices of control [cf. van Dijk 2001: 354]. This power manifests itself in the legal provisions and rules [cf. van Dijk 2001: 355] to which the residents are subjected. The main category of social wrong is the restriction of an individual's freedom, which refers to the practices of total institutions. The reference in the study was the catalogue of features of a total institution, mentioned earlier.

Phase II reflected on the ways social life is structured and organised, which may make it difficult to solve a given problem effectively. It concerns the relationship between the order of discourse (in this case institutional) and the text (regulations), and social practices and activities related to the treatment of people with disabilities [cf. Fairclough 2012: 14]. This is related to the understanding of discourse as a text within a context, with the analysis of the structure of the documents aiming to identify their communicative functions [Duszak 1998: 7; cf. Czyżewski 2008: 26].

Phase III involved reflecting on the place of and need for harm in the social order. In this case, the main issue is the organisation of the DI process and whether it must maintain forms of control and limitations of individual freedom, or if other solutions may be sought to eliminate the relationship of power and domination [cf. Fairclough 2012: 15].

Phase IV was the transition from negative to positive analysis, and it focused on the prospects of overcoming obstacles and solving problems. It required analysing the proposed solutions, namely how discourses, narratives, or arguments (institutional in this case) are contested and replaced by others (supporting or alternative) as part of the ongoing struggle with mainstream strategies [cf. Fairclough 2012: 15].

The analysis does not refer directly to the situations of people in sheltered/ supported housing (which would require a different type of research), though it provides insights into housing management institutions, including the functions and goals of this type of social service.

\section{RESULTS}

Due to the breadth of the topic, only the most important results are presented in this paper. The results relate to phase I (a detailed analysis of the regulations) by showing the principles of sheltered/supported housing. The subsequent phases contain the main threads of the analysis and the directions that need to 
be developed through broader studies; it is important to introduce these (even in passing) in relation to CDS theory. From that point of view, it is necessary to outline the crucial issues regarding each phase (II-IV), especially phase IV, which concerns both the discussion on DI and also potential solutions to the institutionalisation problem. Simultaneously, the introduction of phases II-IV, along with their multithreading, comprises an invitation to a broader academic discussion on the subject. For this reason, phases II-IV have been treated herein not as research results, but as part of a larger discussion on the issue.

\section{PHASE I}

This part of the analysis was split into three areas, referring to the permeability continuum and the aforementioned catalogue of features concerning the functions of NHC as a total institution. The features (reflected in regulations) were ranked from those that most resemble total institution rules (the first area) to the features that are less observable (or even absent) in the analysed material. This made it possible to construct a more nuanced picture of sheltered/protected housing, to show the points where its ideas tend toward the more permeable end of the continuum.

\section{Features of the regulations gravitate towards the total end of the continuum}

At the outset, the provisions in the regulations define the position of the resident in relation to the institutional apparatus to which he/she is subjected; there is no doubt concerning the semantics of the terms, which are in keeping with highly formalised legal documents: "Administrative decision", "order", "obligation", "stay", "compliance", "procedure", and "control".

Obtaining a room in a sheltered/supported apartment is contingent on meeting certain requirements and signing an agreement/contract, including consent to comply with the regulations. Breaking these rules may result in removal from housing. The rights and obligations of residents are regulated (the duties of staff, less frequently), and they stipulate prohibitions and how the apartment will be supervised (which translates into supervision of the residents). A person who moves into sheltered/supported housing receives a series of messages included in a contract that specify the relations and rules of power applicable.

In the regulations, the relationships between staff and charges are professional. The roles of employees are "taking care", "providing support", "mediation", and 
"providing help" [cf. Ochotnica Dolna $\left.5.2^{7}\right]$. The residents are obliged to cooperate with specialised staff, who simultaneously support and control - especially when residents participate in forms of care that allow for individual support/assistance or other types of support [cf. Bełchatów 6.3.4, Jastrzębie-Zdrój 6f; Żary 5.2.14]. The role of the staff may also be to stimulate the residents ("stimulating the activity of residents and their family to meet biological, mental, and social needs" [Jastrzębie-Zdrój 6e]).

The provisions of the regulations show the asymmetry of the relationship between staff and residents, and the strong position of the former. It is sometimes expressed directly: "[the responsibility of the resident is] to respect the recommendations and arrangements of the social worker, including those that exceed the content included in the regulations" [Bełchatów 4.13; cf. Żary 5.2.15], "respecting the recommendations of the [...] manager [...] and caretaker of a sheltered apartment" [Ochotnica Dolna 4.2.5; cf. Tarnowskie Góry 6.7; Komarów-Osada 5.4.10; Pcim 5.10; Jastrzębie-Zdrój 5.2g].

The statutory regulations enter the private sphere of residents' lives, describing certain behaviours in terms of "prohibition", "order", "obligation", and "control", as well as "the right to", or sanctions (loss of the right to stay in the apartment). In many cases, interfering with the intimate sphere of life is associated with the desire to regulate the principles of coexistence between residents, and to ensure that they respect commonly accepted norms. However, it is extremely difficult to establish the boundary between these norms and interfering with an individual's privacy. For the study, it was assumed that it concerns intrusion that exceeds the limits that most people find acceptable - with the awareness of the imprecision and conventionality of such an approach.

Almost all the regulations prohibit alcohol and other intoxicants being brought. There is also an obligation to undergo a breathalyser test [Starogard Gdański 7.6; Żary 5.6], and a ban on visitors who are under the influence of alcohol or other intoxicants [Komarów-Osada 5.4.14]. A frequent practice is to introduce a total smoking ban [Bełchatów 5.2; Komarów-Osada 5.4.6; Kędzierzyn-Koźle 10.4; Kalisz 5.6; Świdnica 6.5; Toruń 4.18; Starogard Gdański 7.3.5; Żary 5.3; Police 13.7; Więcbork 5.1i].

Another type of interference in the intimate sphere of life is allowing employees to enter the apartments "at any time" [Bełchatów 4.14], "including at night” [Starogard Gdański 7.2.15; see Ochotnica Dolna 4.2.14; Żary 5.2 16.17].

7 Numbers refer to relevant articles of facility regulations. The facilities are identified by places in which they are located. 
Supervisors may enter "at any time, during the stay of users, and also during ad hoc inspections during [their] absence" [Żary 2.10]. Residents may also be obliged to "allow authorised persons to visit the apartment" [Odolanów 5.2.7; Pcim 5.11; cf. Jastrzębie-Zdrój 5.3]. Otherwise, the institution "reserves the right to enter the building which constitutes sheltered apartments (including every living room) at any time during the residents' stay there, and in the absence of these people in situations requiring quick access [...]" [Więcbork 5.7; cf. Sadowie 3.3; Tarnowskie Góry 6.8; Piotrków Trybunalski 3.3].

The regulations interfere with contact between residents and people "from outside". There is often a ban on admitting guests during night hours (which may be precisely defined, with the broadest range noted from 19:00 to 9:00 [Starogard Gdański 7.2.9, 7.3; Żary 5.3]). In some provisions, this regime has been eased, and admitting guests at night is possible after obtaining the consent of the caretaker of the apartment and the co-residents [Opatów 8j; Płock 9.5, 9.6, 12.11; Torun 3.10]. Sometimes the possibility for all visits is regulated, which may include the need to report a guest's visit to the "home caretaker or manager" [Komarów-Osada 5.4.15], as well as "at hours agreed with the assistants and after the prior announcement of the visit to the assistants" [Police 9.6].

Another type of interference with privacy is the prohibition on keeping animals [Bełchatów 5.8; Jastrzębie-Zdrój 5.2i; Ochotnica-Dolna 4.2.7; Kędzierzyn-Koźle 10.10; Świdnica 6.10; Torun 4.23; Starogard Gdański 7.3.10; Żary 5.3; Więcbork 5.1j; Opatów 8i; Pcim 6.5] or prohibiting dogs and cats and the need to ask for permission from housing management in the case of other animals [Tarnowskie Góry 9.2].

A further breach of the private sphere may be the residents' obligation to report their absence from the apartment for a period exceeding 24 hours, with at least one day's notice in advance [Starogard Gdański 7.2.11; Komarów-Osada 5.4.16; Kędzierzyn-Koźle 10.12.14; Świdnica 6.14; Ochotnica Dolna 4.2.13; Tarnowskie Góry 6.7; Żary 5.2.12, Odolanów 5.2.6], with an application in writing, for an absence exceeding 48 hours [Pcim 5.13; Racibórz 4.14; Opatów 80], or without specifying a fixed duration [Bełchatów 4.10; Jastrzębie-Zdrój 5.2f]. In one case, the absence must be reported even a week in advance [Police 13.6]. There was also a distinction drawn between justified and unjustified absences [Police 8.2] and the need for justification when it occurs [Ochotnica Dolna 2.4; Płock 4.7e; Opatów $8 \mathrm{p}$ - written justification]. In one case, the obligation to "report to the apartment guardian every planned departure from the apartment during the curfew and the estimated time of return" was introduced, and in case of failure to 
meet the deadline, to inform "the apartment guardian about the expected time of return" [Świdnica 6.13].

In two cases, direct control over leaving the area of the apartment was used: "leaving the premises of the sheltered apartment may take place after prior notification to the guardian and entering the exit book" [Komarów-Osada 5.5]; "Every resident leaving the Apartment should be agreed and reported to the assistant" [Police 13.5]. Interference with the intimacy of an individual should also include the obligation to "care for personal hygiene, external appearance and order in one's own things and around oneself" [Kędzierzyn-Koźle 10.7; Opatów 8c; cf. Więcbork 5.1.c], and to keep their room clean [Świdnica 6.7]. Another type of intrusion in the private sphere is the need to obtain consent to use anything other than basic equipment [Więcbork 2.5.a], or for "bringing in and storage by the resident [of] his own property and items that do not belong to the apartment's equipment" [Świdnica 4.1; cf. Racibórz 9.7].

Interestingly, some regulations emphasise residents' rights to intimacy or to make choices about how their free time is spent [Jastrzębie-Zdrój 5.1d,e,f; Police $9.1,3,4]$, e.g., "maintaining contact with family and friends, including receiving visits" [Police 9.5], "participating in activities of daily living and participating in social life at social, religious and environmental levels" [Police 9.6]; "safe and proper conditions for rest, study, own work, preparing meals" [Kalisz 3.1; Pcim 4.1; Żary 5.1] "performing hygienic procedures" [Piotrków Trybunalski, Annex 2.1.1]; "deciding on matters relating to oneself; receiving visits from relatives and friends in the apartment or meeting room; spending free time freely; periodically staying outside the sheltered apartment after prior notification of the staff on duty" [Kędzierzyn-Koźle 9.2,3,4,5]. The emphasis on these principles should arouse concern, as including them in the regulations could be a form of control; this might seem obvious and understood in terms of human rights. In this context, the following provision is disturbing: "the resident has the right to contact the family in particularly justified cases with the consent of the Assistant or Guardian [and] telephone contact - 15 minutes per day in the evening hours, no later than 10.00 p.m. with the consent of the Assistant or Guardian" [Jastrzębie-Zdrój 5.1h]. This provision indicates the control of intermediation between residents and the outside world. However, this aspect does not appear in the other regulations and should be considered an isolated case.

The residents' lives are largely governed by the housing institutions. A conflict with an employee or failing to comply with the regulations may lead to a resident being removed from the apartment, thus depriving him/her of a basic commodity. 
This may make the residents highly dependent on the institution due to fears about being removed from the apartment in the future

The functioning of sheltered/supported housing is related to the category of "supervision" (which sometimes appears literally in the regulations) performed by carers, coordinators, directors, managers, assistants, and social workers. They care less about the residents observing the daily schedule than fulfilling the regulations, and they also provide support.

Most of the regulations assume the monitoring of relations between residents, directly communicating the residents' obligation to inform the staff about problems, difficulties, and misunderstandings while they are in a sheltered/supported apartment [Bełchatów 4.11; Jastrzębie-Zdrój 5.2.h; Żary 5.2.13; Komarów-Osada 5.4.11; Kędzierzyn-Koźle 10.15; Więcbork 5.1g; Opatów 8h; Świdnica 6.9; Toruń 4.22; Racibórz 9.4; Ochotnica Dolna 4.2.6.6].

In the regulations, the category of "obligation" appears, which is expressed in the form of a separate (and sometimes extensive) paragraph, which describes the residents' obligations. They also include particular activities, such as "the active use of the offered forms of support" [Bełchatów 4.4.12; Ochotnica Dolna 4.2.15; Starogard Gdański 7.2.13], training in areas such as self care, household management, cooking skills, budgeting, social resourcefulness, motivation and self-assessment, spending free time [Płock 10.7], implementing a program for becoming independent [Żary 6.1], but also the obligation to "participate in running a common household, including activities such as cooking, cleaning, washing" [Police 10.9]. Neglecting to perform duties could be punished by losing the right to use the apartment: "the resident loses the right to stay in the apartment in the event of failure to implement the independence program" [Starogard Gdański 8.1.5].

The existence of regulations implies that their observance is monitored, which is performed in the course of the duties of the institution that runs the apartment. Sometimes it may be expressed directly: "stays in sheltered housing and the process of independence or support are subject to assessment at least once every 3 months" [Żary 4.11] or "control of compliance with the rules by the caretaker of the apartment or an authorised representative of the Centre may be performed at any time of the day" [Racibórz 9.6]. However, there is no feedback process in the regulations: there are no provisions that allow residents to express their opinions or to co-decide on matters related to the apartment (the exception being the opportunity to participate in building a support plan). 


\section{Features of the regulations that partially gravitate towards the total end of the continuum}

It is possible to indicate the features of regulations that are less strict than those of NHC. Most importantly, the regulations are generally the same for all residents, though regarding the residents' activation, some differentiation is allowed based on their reasons for being in the institution. It later influences the obligation to participate in various types of activities and use active forms of support [Bełchatów; Racibórz 8.3]. It may be associated with establishing an individual plan/program of support/self-empowerment (Bełchatów, Płock, Starogard Gdański), raising social competencies (Sadowie), or the obligation to take up employment [Kalisz 1]. It indicates that in this aspect, residents may be treated differently and obliged to undertake various activities within the available catalogue of activation instruments (under the penalty of losing their place in the apartment). Thus, getting a place in an apartment was associated with the need to spend a certain amount of time in particular places and during appointed hours, although the choice of activity type was left to the residents. In most cases, the regulations did not include a catalogue of compulsory actions, nor did they describe a uniform plan for the daily activities of all the residents.

\section{Features of regulations that indicate more permeability of sheltered/protected housing}

The analysis does not indicate that people living in sheltered/supported housing are obliged to spend most of their time in one place. The regulations of most of the analysed apartments did not provide for strict organisation of the day, apart from night hours at scheduled times. However, it is notable that some of the housing arrangements surveyed were part of activation/self-empowerment projects, which assumed mandatory attendance during specific classes. Thus, it did lead to certain plans for the day, as in the case of housing in Racibórz [8.3], where residents were allowed to miss a maximum of $25 \%$ of the classes.

The regulations do not provide much information regarding the rationing of space. The possibility of moving residents to another room or apartment is not mentioned. Sometimes a division between a room and the rest of the flat [Bełchatów 2.3.1] is indicated, and these spaces are used on slightly different principles (the room should be assumed to be a private zone, although with the previously-indicated opportunities to interfere with it). 


\section{DISCUSSION}

The discussion is organised in order of the previously presented principles of the adopted version of the CDA. It is split into phases II-IV, reflecting the issues set out in the methodological part of the article.

\section{PHASE II}

There is a visible relationship between the institutional order of discourse - manifested as regulations - and the social practices that relate to people with disabilities. The practice related to the supervision and control of these groups as "subordinate" and "dependent" is firmly entrenched normatively and culturally. Departing from that may cause concerns related to the responsibility of the institution for its clients, at various levels: functional (health, rehabilitation), ethical (possible socially unacceptable behaviour), and legal (responsibility for the illness or death of a resident).

When regulations are considered as texts within a context, with their own logic and fixed structure (repeated in most of the studied cases), they also constitute a strong message. On the one hand, the text is addressed to the inhabitants (establishing their subordination). On the other hand, it comprises a form of communication that goes "outside", to the wider public, containing a message about safety, professionalism, responsibility, purposefulness, and care.

Therefore, changing the institutional paradigm to the human-rights paradigm is difficult when structuring social life, where the supervision and protection of the discussed group are emphasised at the expense of their self-determination.

\section{PHASE III}

The structure and semantics of the regulations illustrate an institutional form of thinking about sheltered/supported housing, which seems to imply that a transfer of institutional practices is a necessary condition to maintain an appropriate line of action. The provisions of the regulations are most likely the result of the institutions' previous experiences (e.g., those derived from the NHC service) related to the problem of alcohol abuse, disturbing the quiet hours, socially reprehensible behaviours, or destroying property.

The problem of transferring institutional practices to sheltered/supported housing stems in part from a paradox in how institutions organise DI: institutions that have practices, burdens, and goals attempt to transpose these aspects 
onto an unknown field, i.e., DI. This is evident in the discourse contained in the regulations, which clearly shows how difficult it is to change the thinking in this area and move from a category of institutional security to a category of ensuring individual freedom. Hence, sheltered/supported housing (with its institutional burden) is not a complete response to the DI proposal; it is only a type of strength test (or a transition period, with no clearly-defined subsequent stage).

A significant difficulty is also seen in the functions of some of the housing associated with projects (e.g., based on external temporary sources) and its burdens related to the need to successfully implement the independence programme or participate in specific classes. In such cases, support is made conditional (a resident can be removed from the apartment for failing to meet the project assumptions), and is not a simple assurance of the implementation of human rights.

Although the permeability of medical (or semi-medical) institutions could be considered a positive indicator of social change, there are also difficult aspects of the DI process regarding the security and safety of inhabitants [Quirk, Lelliott, and Seale 2006: 2114], which is not without significance for the presented discussion. Attention should be paid to the dilemma in allowing an individual's freedom and the issue of his/her safety that must be resolved by the operators of sheltered/ supported housing. In particular, this pertains to groups with limited decisionmaking abilities (such as people with intellectual disabilities) and who may also be exposed to negative effects given a lack of continual interest in their activities (e.g., the possibility of getting lost, becoming a victim of a crime, being stigmatised as a result of breaking social norms). It is an extremely challenging issue, and in this context, using restrictions and certain forms of control and supervision in the DI process is understandable. The difficulty, however, is in indicating when this control supports the individual and when it becomes excessive. Certain elements that can be described in the category of social wrong are not fully possible to eliminate, but an important goal of DI should be to limit them.

\section{PHASE IV}

While the idea of sheltered/supported housing should be considered a legitimate and valuable part of the DI process, attention should be paid to another way of organising it to prevent possible abuses of power and human rights violations. It is worth considering at least three main counter-arguments raised by DI supporters in response to the institutional discourse and its mainstream strategies.

Firstly, a central problem (and an argument often raised by institutions) is the need to take responsibility for the client (resident of the facility). When 
a contract is signed, the resident becomes a "guest", who should be properly guided and shaped. Strict regulations protect both the resident and the institution. An alternative scenario is "personal assistance" combined with supported decisionmaking (where necessary, in the case of people with intellectual disabilities). It could effectively eliminate the institutional concerns raised here by transferring responsibility to the assistant and the client (in proportions regulated between them). Such a solution, however, would require the independence of personal assistance, so that it does not become part of the institution. It seems difficult at the present stage (it would involve using a "personal budget" - an instrument allowing the free choice of service provider - which includes the individuals; however, this system does not yet function in Poland).

A second important issue is related to the funds at the disposal of local governments, which translates into a small number of apartments that can be managed. The narrative of housing shortages (as a general problem) appears broadly. Local governments indicate difficulties in organising social/council housing, emphasising numerous problems ranging from obtaining them, to carrying out renovations, and their vandalising by users. A counter-argument in favour of DI is the large living wages of NHC residents, which could be used for the organisation of housing. Amounts in the range of 4,000-10,000 PLN allocated monthly to the maintenance of one NHC resident is compelling, but the difficulty is the transitional period involved in transforming large facilities into sheltered/ supported housing, which requires maintaining both infrastructures for a time. The arguments related to equal rights support the inclusion of protected/assisted housing in the available pool of social/council housing sites. The regulations of current housing are specialised and oriented less to housing (in the sense of longterm residence) than to implementing a certain program. Signing contracts and regulations for communal housing by the analysed group of people would make them equal to other groups, and would constitute an element of social inclusion. By contrast, the current model of sheltered/supported housing is a type of segregation.

The third issue is the provisional nature of a stay in housing and institutional thinking, in the category of a "short term project". This leads to the belief (one reflected in the analysed regulations) that sheltered/supported housing must have the purpose of "adapting" and "educating" the individual. This seems to assume that there should be a "plan" that will end in them leaving the apartment. The counter-argument is that the purpose of sheltered/supported housing is to ensure the human rights that one is entitled to, in free, permanent, and reliable living with adequate support - without short term project burden and statutory sanctions. 


\section{CONCLUSIONS}

In the light of the above, and the fact that DI (as expressed in the idea of sheltered/ supported housing) requires supportive institutions, it should be considered whether a DI process exists or rather the creation of "scattered institutions", which consists of separate apartments (sometimes concentrated in one place). At this stage, it is worth quoting a fragment of the General Commentary to Art. 19 of the CRPD: "where we live and with whom, what we eat, whether we like to sleep in or go to bed late at night, be inside or outdoors, have a tablecloth and candles on the table, have pets or listen to music. Such actions and decisions constitute who we are" [CRPD 2017: 16]. The idea of individual freedom portrayed here does not fully overlap with the results of the analysis presented in this study. The inability to choose co-residents, the need to register for longer exits, or the ban on having pets are just some of the aspects that exemplify the institutional nature of sheltered/supported housing.

The permeability of this type of housing, expressed in the discourse observed in the regulations, seems to be convergent with the permeability of NHC. However, sheltered/protected housing goes beyond the "NHC world" and offers a broader spectrum of permeability in some respects (e.g., inhabitants are not obliged to spend time in the same place; the day activities are not strictly planned; activities can differ for various inhabitants). It is also possible that there are particular NHC regulations that are much more permeable than the analysed material and which might lead to the conclusion that the stringency of regulations depends not only on the law but also on the practices and experiences of particular institutions.

Notwithstanding the above, the most disturbing phenomena are perhaps the forms of control and protection of residents which may limit individual their freedom in fundamental ways. This raises the question as to whether sheltered/supported housing, in the opinion of the institutions running it, is indeed a part of the DI process, or an extension of institutional benefits. The main goal here is to solve the immediate problems of people who have found themselves in difficult circumstances, not to construct a form of permanent support. There is a clear assumption that people who end up in sheltered/supported housing are in some way "problematic". This leads to a need to ensure their safety, but also to provide "educational" activities to help them "become independent" (without specifying what this means).

The analysis of the regulations also leads to the conclusion that assisted and sheltered/supported housing do not differ in terms of quality. In both cases, the regulations are similar, and sometimes literally the same. Furthermore, the stability of these forms assumed at the beginning of the study (the possibility of 
long-term residence) turned out to be illusory; most of the surveyed regulations emphasised the duration of stay, and the goal was to end the stay in the apartment.

In the case of sheltered/supported housing, it seems that DI is narrowed most of all to the introduction of quantitative changes (a small number of people living in the apartment or facility). Qualitative changes are also visible, but methods that ensure individual freedom are not the main focus: the dominant category is safety. That said, certain groups, including people with intellectual disabilities (especially more profound ones) who require more support, are likely to require activities that may develop into supervision under all circumstances. This may lead to over-control in practice.

DI is generally perceived as a desirable solution for Polish social policy, but interpretations about the concept are not self-evident. An example is the controversy over the Draft Strategy for the Development of Social Services for 2021-2035. The document had been under joint preparation by the Ministry of Family and Social Policy and non-governmental organisations. However, the Ministry finally published its own version of the Strategy, which differs from the other social partners' proposals. The Strategy included following sentence: "however, the deinstitutionalisation process should be carried out very thoughtfully, prudently, and responsibly, so as not to dismantle support systems, but only to relocate the organisation of services to local environments. Hence, the Strategy adopts a long-term approach to this process, spread over time until 2035" [Strategy 2021: 7]. Despite the declared support for DI, the Ministry seems to be trying to maintain a certain status quo and avoid radical (and rapid) changes ${ }^{8}$. The emphasis on not dismantling the current system shows a manner of thinking that corresponds to the results of the presented study: institutions responsible for implementing DI are embedded in their own historical practices, which may be perceived as both valuable experience and a burden in the DI process.

At this point, a question arises as to whether sheltered/protected housing in Poland is perceived by its operators as part of DI (as the Draft Strategy for the Development of Social Services for 2021-2035 suggests) or a way to increase the number of places for additional inhabitants in the institutional system. If the first case is true, sheltered/protected housing could be considered a form of "apparent action" - a term proposed by Lutyński [1996: 127]. It is possible

As a response, The $7^{\text {th }}$ (Polish) Congress of People with Disabilities, which brings together non-governmental organisations as well as independent persons, carried out a debate this year (2021) under the slogan, "We cannot wait any longer". One of the final proposals of the Congress was "The adoption of an ambitious Deinstitutionalization Strategy with specific indicators for individual years, assuming the adoption of key legislative changes on specific dates" [PFON 2021]. 
to indicate at least two features of "apparent action" in relation to sheltered/ protected housing in Poland. Firstly, "apparent actions" are officially considered essential to implementing socially important goals. Secondly, these goals are not actually implemented (or contributions are not made to their implementation). Taking into consideration the results of the presented research, one could question whether we are dealing with "apparent DI". It is not possible to provide a reliable answer here, and it demands broader exploration, although the problem seems worth considering; if the result was found to be positive, then another solution for sheltered/protected housing should be demanded.

At the same time, regarding the NHC facilities, it should be noted that staying in the same sheltered/supported apartment may have a subjectively different character for particular people, depending on their psychophysical condition and level of independence. Therefore, formulating research categories to identify "social wrongs" (or, more broadly, violations of human rights) is extremely difficult. Some provisions (such as the prohibition of drinking alcohol or smoking, or the need to report absences from the apartment) should be seen through the lens of the characteristics of particular residents (such as health contraindications, dementia, or intellectual disability), which means that the issue of applying control and supervision cannot be assessed in an unequivocally negative manner.

The presented study provides some insights into the modes of thinking of sheltered/supported housing operators and shows the tendency to integrate crucial isolation practices into the DI process with greater permeability at the same time. However, it does not provide insight into the execution of daily practices. At this point, it is worth paying attention to the "practice turn" found in sociological research (as in other fields), where "practices bespeak such desires as those to free activity from the determining grasp of objectified social structures and systems, to question individual actions and their status as the building-blocks of social phenomena, and to transcend rigid action/structure oppositions" [Schatzki 2005: 10]. The "practice turn" owes its shape to various philosophical, sociological, and cultural theorists but its ethnomethodological background is particularly interesting concerning the discussed research. Since formal organisations are based on bureaucratic rules (perceived as a kind of "ideal set"), the question is how their employees would cope with their application within day-to-day routines. A question thus posed does not concern the violation of rules, or establishing hidden rules (to deal with the official ones); it focuses on "practices employed by bureaucrats to render such idealisations relevant prescriptions, justifications, descriptions, or accounts of their activities". In other words, "a related issue of interest here is the way in which 'departures' from the formal organizational plan 
are dealt with" [Zimmerman 1970: 223-224]. Such an approach is based on the rationality of decisions made and "relies upon a taken-for-granted grasp of, and implicit reference to, the situated practical features of task activity" [Zimmerman 1970: 225]. These lead to proposals to examine the practices employed in sheltered/supported housing regarding their regulations. Comparative research of similar rules applied in nursing homes and sheltered/supported housing run by the same institution (e.g., municipal authorities or a non-governmental organisation) would be especially interesting. The main issue would be if the employees applied the same or different explanations of their day-to-day routines in both kinds of facilities. In other words, does being (or not being) part of DI (as a facility) involve any special interpretations of "ideal rules"?

This proposal could be combined with a proposal to examine the quality of life of the residents of sheltered/supported housing, using methods other than CDA. It would make it possible to determine the operational level of institutionalisation of these housing sites, and to learn about the subjective perspectives of residents related to control and isolation practices. A working hypothesis can be put forward: the quality of life in sheltered/supported housing is better, which is related to the departure from the often "hospital-like" character of NHC as collective accommodation facilities. Based on observation or interview techniques, the research could reveal more regarding the permeability of sheltered/supported housing. The main question is whether (or to what extent) impermeability that arises from regulations would be transferred to everyday practices. It could lead to a more nuanced picture of a subject that is not entirely possible to obtain in the presented study.

As specified in the General Commentary to Art. 19, "neither large-scale institutions with more than a hundred residents nor smaller group homes with five to eight individuals, nor even individual homes can be called independent living arrangements if they have other defining elements of institutions or institutionalization" [CRPD 2017: p.16c]. In this context, one might consider whether a change of form (from a multi-person institution to housing) is enough to carry out DI, or whether it is necessary to change ways of thinking about the residents of NHC facilities by considering their situations primarily in terms of freedom and human rights. Respect for an individual's freedom, however, may run counter to ensuring that person's safety; this leads to the proposal of looking for a path other than sheltered/supported housing. Perhaps DI should be based on the development of personal assistance combined with the inclusion of potential NHC clients in local social/council housing programs. This would be a proposal that is consistent with the principle of including people with disabilities (and older 
people) in local communities, thereby preventing the social isolation caused by institutionalisation. At the same time, however, doing so raises new problems (such as responsibility and legal empowerment of personal assistance).

\section{BIBLIOGRAPHY}

Act. 2004. Ustawa z dnia 12 marca 2004 r. o pomocy spolecznej. Dz. U. 2004 Nr 64 poz. 593.

CRPD. 2006. UN Convention on the Rights of Persons with Disabilities.

CRPD. 2017. General comments, General comment on article 19: Living independently and being included in the community. Committee on the Rights of Persons with Disabilities, Eighteenth session, 14-31 August 2017, Item 8 of the provisional agenda.

Czyżewski Marek. 2008. Elementy i całości. O niektórych dylematach analizy dyskursu. In: Analiza dyskursu w socjologii i dla socjologii. A. Horolets (ed.), 19-29. Toruń: Adam Marszałek.

Czyżewski Marek, Michal Otrocki, Tomasz Piekot, Jerzy Stachowiak. 2017. Wprowadzenie. In: Analiza dyskursu publicznego. Przeglad metod i perspektyw badawczych. M. Czyżewski, M. Otrocki, T. Piekot, J. Stachowiak (eds.), 9-25. Warszawa: Wydawnictwo Akademickie SEDNO sp. z o.o.

Duszak Anna. 1998. Tekst, dyskurs, komunikacja międzykulturowa. Warszawa: Wydawnictwo PWN. Fairclough Norman. 1992/2006. Discourse and social change, Cambridge, Malten: Polity Press.

Fairclough Norman. 1995. Critical discourse analysis: The critical study of language, London, New York: Longman.

Fairclough Norman. 2005. "Critical discourse analysis", Marges linguistiques 9: 76-94.

Fairclough Norman. 2012. Critical discourse analysis. In: The Routledge handbook of discourse analysis. J. P. Gee, M. Handford (eds.), 9-20. Routledge.

Goffman Erving. 1991. Asylums. Essays on the social situation of mental patients and other inmates. London: Penguin Books.

Goodley Dan. 2017. Disability studies. An interdisciplinary introduction. SAGE.

Grue Jan. 2011. "Discourse analysis and disability: Some topics and issues". Discourse \& Society 22(5): 532-546.

Guidelines. 2019. Wytyczne w zakresie realizacji przedsięwzięć w obszarze włączenia społecznego i zwalczania ubóstwa z wykorzystaniem środków Europejskiego Funduszu Społecznego i Europejskiego Funduszu Rozwoju Regionalnego na lata 2014-2020. Warszawa: Minister Inwestycji i Rozwoju.

Horkheimer Max. 1972/2002. Critical theory. Selected essays. Translated by M.J. O'Connel and others. New York: The Continuum Publishing Company.

Jagura Jarosław. 2020. Domy pomocy społecznej w dobie pandemii. Doświadczenia, potrzeby, wyzwania. Warszawa: Helsińska Fundacja Praw Człowieka.

Kurowski Krzysztof. 2014. Wolności i prawa człowieka i obywatela z perspektywy osób z niepetnosprawnościami. Warszawa: Biuro Rzecznika Praw Obywatelskich.

Lutyński Jan. 1996. Działania pozorne. In: Wokót problemów działania społecznego. Wybór tekstów i przykładów projektów dziatania. E. Marynowicz-Hetka, J. Piekarski (eds.), 125-138. Warszawa: Interart.

Marciniak-Madejska Natalia, Rafal Stenka, Karolina Weiner.(n.d.). Podręcznik dobrych praktyk $w$ zakresie deinstytucjonalizacji. Rozwiazywanie problemu bezdomności i wykluczenia 
mieszkaniowego w oparciu o usługi świadczone w lokalnej społeczności. Poznań: Regionalny Ośrodek Polityki Społecznej w Poznaniu.

Mayr Andrea. 2015. Institutional discourse. In: The handbook of discourse analysis, Second Edition, Vol. II, D. Tannen, H.E. Hamilton, D. Schiffrin (eds.), 755-774. John Wiley \& Sons, Inc. except for Chapter 16 (C) Bloomsbury Publishing Plc.

Mladenov Teodor, Gabor Petri. 2019. "Critique of deinstitutionalisation in postsocialist Central and Eastern Europe”, Disability \& Society, DOI: 10.1080/09687599.2019.1680341.

MRiF. 2016. Wytyczne w zakresie realizacji przedsięwzięć w obszarze włączenia społecznego i zwalczania ubóstwa z wykorzystaniem środków Europejskiego Funduszu Społecznego i Europejskiego Funduszu Rozwoju Regionalnego na lata 2014-2020. Warszawa: Minister Rozwoju i Finansów.

Niedbalski Jakub. 2013. „Między kontrolą a autonomią - instytucjonalne uwarunkowania życia niepełnosprawnych intelektualnie mieszkańców domu pomocy społecznej”. Niepetnosprawność - zagadnienia, problemy, rozwiąania IV/2013(9): 47-63.

Organisations. 2020. List otwarty do Prezydenta RP i Prezesa Rady Ministrów. https://publicystyka.ngo.pl/rozwoj-uslug-spolecznych-i-zdrowotnych-to-koniecznosc-apel-do-prezydenta-i-premiera [access: 29.12.2020].

Posłuszny Lukasz. 2017. “Instytucje totalne dzisiaj: stan badań, krytyka, rekonfiguracje”. Studia Socjologiczne 4(227): 121-145.

PFON. 2021. Uchwała kończąca VII Kongres Osób Niepetnosprawnych w dniu 23 października 2021 r. Polskie Forum Osób Niepełnosprawnych. https://pfon.org/aktualnosci/uchwala-konczaca-vii-kongres-osob-niepelnosprawnosciami-w-dniu-23-pazdziernika-2021-r/ [access: 03.11.2021].

Quirk Alan, Paul Lelliott, Clive Seale. 2006. "The permeable institution: An ethnographic study of three acute psychiatric wards in London”. Social Science \& Medicine 63(8): 2105-2117.

Sadowski Ireneusz. 2014. „Współczesne spojrzenie na instytucje: Ewolucja pojęć, problem modelu aktora i poziomy analizy instytucjonalnej". Przeglad Socjologiczny 3: 89-114.

Schatzki Theodore R. 2005. Practice theory. In: The practice turn in contemporary theory. T.R. Schatzki, K. Knorr Cetina, E. von Savigny (eds.), 10-23. Taylor \& Francis e-Library.

Sulikowski Adam. 2014. Perspektywy zastosowań metod Krytycznej Analizy Dyskursu w badaniach nad prawem. Kilka uwag. W: Rozprawa o metodzie prawa i polityki. M. Sadowski, A. Spychalska, K. Sadowa (eds.), 99-111. Wrocław: Wydawnictwo Beta-Druk; Wydział Prawa, Administracji i Ekonomii Uniwersytetu Wrocławskiego.

Šiška Jan, Julie Beadle-Brown. 2011. "Developments in deinstitutionalization and community living in the Czech Republic". Journal of Policy and Practice in Intellectual Disabilities 8(2): $125-133$.

Strategy. 2020. Strategia na rzecz osób z niepełnosprawnościami. Załącznik do uchwały nr 27 Rady Ministrów z dnia 16 lutego 2021 r. (poz. 218). https://monitorpolski.gov.pl/ M2021000021801.pdf [access: 26.02.2020].

Strategy. 2021. Strategia rozwoju usług społecznych. Projekt z dnia 22.09.2021. https://www. gov.pl/web/rodzina/projekt-uchwaly-rady-ministrow-w-sprawie-ustanowienia-politykipublicznej-pt-strategia-rozwoju-uslug-spolecznych-polityka-publiczna-na-lata-20212035? fbclid=IwAR32H7JGQr1bOS5 cpbR7KqOL3LLBIv83Xi1goDuGa5MLg09y_ k2BWQRAlPU [access: 03.11.2021]. 
Tarkowska Elżbieta. 1997. Ludzie w instytucji totalnej. Przypadek domów pomocy społecznej. In: Upośledzenie w społecznym zwierciadle, A. Gustavsson A., E. Zakrzewska-Manterys (eds.), 121-138. Warszawa: Wydawnictwo Żak.

van Dijk Teun A. 2001. Critical discourse analysis. In: The handbook of discourse analysis. D. Schiffrin, D. Tannen, H. Hamilton (eds.), 352-371. Oxford: Blackwell Publishers.

Wodak Ruth, Michael Meyer. 2009. Critical discourse analysis: History, agenda, theory and methodology. In: Methods of Critical Discourse Analysis. R. Wodak, M. Meyer (eds.), 1-33. London: SAGE.

Zbyrat Teresa. 2012. „Instytucje opieki totalnej jako forma zniewolenia i kontroli nad człowiekiem potrzebującym pomocy - na przykładzie domów pomocy społecznej”, Roczniki Nauk Społecznych 4(40)2: 51-69.

Zimmerman Don H. 1970. The practicalities of rule use. In: Understanding in Everyday Life. J.D. Douglas (ed.), 221-238. Chicago: Aldine Publishing Company.

\section{Analysed materials: Sheltered/supported housing regulations}

Bełchatów. 2020. Regulamin mieszkania chronionego, Załącznik do Zarządzenia Nr 38/2020 $\mathrm{z}$ dnia 20 sierpnia $2020 \mathrm{r}$.

Jastrzębie-Zdrój. 2018. Regulamin funkcjonowania mieszkania chronionego wspieranego dla osób niepełnosprawnych, Załącznik nr 2 do Zarządzenia Nr 31//2018 Dyrektora Ośrodka Pomocy Społecznej w Jastrzębiu-Zdroju z dnia 18.07.2018 r.

Kalisz. (n.d.). Regulamin pobytu w mieszkaniu wspomaganym, Fundacja Ludwik.

Kędzierzyn-Koźle. 2018. Zarządzenie nr 17/2018 Dyrektora Miejskiego Ośrodka Pomocy Społecznej w Kędzierzynie-Koźlu z dnia 16 lipca 2018 r. w sprawie wprowadzenia Regulaminu Organizacyjnego Mieszkań Chronionych przy Miejskim Ośrodku Pomocy Społecznej w Kędzierzynie-Koźlu.

Komarów-Osada. 2018. Regulamin organizacyjny mieszkania chronionego wspierane - Gminny Dom Rolnika, Załącznik do Uchwały Nr XXXIX/280/18 Rady Gminy Komarów-Osada z dnia 26 września 2018 r.

Ochotnica Dolna. (n.d.). Regulamin funkcjonowania mieszkania chronionego, Gminny Ośrodek Pomocy Społecznej w Ochotnicy.

Odolanów. (n.d.). Regulamin mieszkania chronionego, Załącznik Nr 4 do Regulaminu Organizacyjnego Gminno - Miejskiego Centrum Pomocy „Wiara - Nadzieja - Miłość” w Odolanowie.

Opatów. 2016. Regulamin Mieszkania Chronionego w ramach mieszkania wspomaganego zarządzanego przez Powiatowe Centrum Pomocy Rodzinie w Opatowie, Załącznik Nr 1 do uchwały Nr 76. 114. 2016 Zarządu Powiatu w Opatowie z dnia 29 grudnia 2016 r.

Pcim. 2014. Zarządzenie Nr 50/2014 Wójta Gminy Pcim z dnia 2 kwietnia 2014 r. w sprawie: wprowadzenia Regulaminu Organizacyjnego Mieszkania Chronionego.

Piotrków Trybunalski. 2017. Regulamin mieszkań wspomaganych, Załącznik Nr 4 do Regulaminu rekrutacji i uczestnictwa w projekcie „Razem możemy więcej”, Miasto Piotrków Trybunalski w partnerstwie ze Stowarzyszeniem Koło Pomocy Dzieciom Niepełnosprawnym oraz towarzyszeniem Centrum Pomocy PANACEUM, 2017.

Płock. 2014. Regulamin pobytu w mieszkaniach chronionych przy ul. Generała Tadeusza Kutrzeby 19 w Płocku, Zał. nr 1 do Zarządzenia Nr 74/2014 Dyrektora MOPS w Płocku $\mathrm{z}$ dnia 8.12.2014 r.

Police. (n.d.). Regulamin Mieszkania Chronionego Wspieranego Polskiego Stowarzyszenia na rzecz Osób z Niepełnosprawnością Intelektualną Koło w Policach. 
Racibórz. 2020. Regulamin Mieszkań Wspomaganych Dziennego Domu Pomocy Społecznej „,przy Placu Wolności” w Raciborzu, Załącznik do Zarządzenia NR OPS.0202.102.2020 Dyrektora Ośrodka Pomocy Społecznej w Raciborzu z dnia 17.11.2020 r.

Sadowie. 2019. Regulamin mieszkań wspomaganych w ramach projektu „Program wsparcia osób niesamodzielnych i wykluczonych społecznie w gminie Sadowie" Projekt wspólfinansowany ze środków Unii Europejskiej w ramach Europejskiego Funduszu Społecznego Poddziałanie RPSW.09.02.01 Rozwój wysokiej jakości usług społecznych (Aktualizacja z dnia 23.08.2019 r.).

Starogard Gdański. 2018. Regulamin mieszkania chronionego mieszczącego się przy ul. T. Kościuszki 129 w Starogardzie Gdańskim, Załącznik do Zarządzenia Nr 29/2018 Dyrektor Miejskiego Ośrodka Pomocy Społecznej w Starogardzie Gdańskim z dnia 14 grudnia 2018 r. w sprawie Regulaminu Mieszkania chronionego przy ul. T. Kościuszki 129 w Starogardzie Gdańskim.

Świdnica. 2019. Regulamin użytkowania mieszkań wspomaganych w projekcie pn. „Świdnickie Jaskółki” RPDS.09.02.01-02-0001/18 współfinansowanym ze środków Unii Europejskiej w ramach Europejskiego Funduszu Społecznego, Oś priorytetowa 9. Włączenie społeczne, Działanie 9.2. Dostęp do wysokiej jakości usług społecznych, Poddziałanie 9.2.1. Dostęp do wysokiej jakości usług społecznych - konkursy horyzontalne, Regionalnego Programu Operacyjnego Województwa Dolnośląskiego na lata 2014-2020, Fundacja Rozwoju Ekonomii Społecznej w partnerstwie z Gminą Miasto Świdnica, 2019.

Tarnowskie Góry. 2017. Regulamin Zespołu Mieszkań Chronionych w Tarnowskich Górach, Załącznik Nr 4 do Regulaminu Organizacyjnego Miejskiego Ośrodka Pomocy Społecznej, 2017.

Toruń. 2017. Regulamin organizacji i zasad funkcjonowania mieszkania wspomaganego, Środowiskowy model wsparcia osób dorosłych z niepełnosprawnością intelektualną, wypracowane w ramach projektu „Lokalne zasoby, środowiskowe wsparcie”, Fundacja na rzecz Osób Niepełnosprawnych Arkadia z siedzibą w Toruniu, Daj Szansę Fundacja na Rzecz Rozwoju Dzieci Niepełnosprawnych z siedzibą w Toruniu, Stowarzyszenia Wspierania Osób Niepełnosprawnych SUBICERE z siedzibą w Radziejowie oraz Kujawsko-Pomorska Federacja Organizacji Pozarządowych z Torunia, 2017.

Więcbork. 2010. Regulamin organizacyjny mieszkań chronionych w Więcborku, Załącznik do Zrządzenia Nr 0161/5/2010 Dyrektora MGOPS z dnia 5 lipca 2010 r.

Żary. (n.d.). Regulamin organizacyjny mieszkania chronionego mieszczącego się przy ul. Piastowskiej 6/1 w Żarach, Miejski Ośrodek Pomocy Społecznej w Żarach.

Zbigniew Gtąb

\title{
OD INSTYTUCJONALIZACJI DO (DE)INSTYTUCJONALIZACJI - PROBLEM TRANSFERU PRAKTYK IZOLACYJNYCH Z DOMÓW POMOCY SPOŁECZNEJ DO MIESZKALNICTWA CHRONIONEGO I WSPOMAGANEGO W POLSCE
}

\author{
Streszczenie
}

W trakcie pandemii COVID-19 powróciła dyskusja dotycząca kwestii funkcjonowania domów pomocy społecznej (DPS) jako instytucji przyczyniających się do społecznej izolacji mieszkańców, a także deinstytucjonalizacji - jako alternatywy dla zbiorowych form zamieszkania - w postaci mieszkań chronionych i wspomaganych $\mathrm{m}$. in. w Polsce. 
Celem badań była analiza wspomnianych form mieszkalnictwa pod kątem sposobu postrzegania i rozumienia deinstytucjonalizacji przez twórców mieszkań chronionych i wspomaganych przeznaczonych dla osób z niepełnosprawnościami.

Zastosowaną perspektywą jest koncepcja przenikalności instytucji umieszczonej na kontinuum pomiędzy instytucją przenikalną i totalną. W badaniach zastosowano krytyczną analizę dyskursu, w której poddano analizie 20 regulaminów mieszkań chronionych i wspomaganych.

Wyniki analiz wskazują na praktykę przenoszenia elementów myślenia instytucjonalnego i ograniczania praw człowieka do form mieszkalnictwa mającego stanowić wstęp lub też realizację idei deinstytucjonalizacji. Myślenie o mieszkaniach chronionych i wspomaganych nadal zawiera wiele cech, które czynią z nich byty bliższe instytucjom totalnym na kontinuum przenikalności.

Słowa kluczowe: instytucja przenikalna, instytucja totalna, deinstytucjonalizacja, mieszkalnictwo chronione wspierane, mieszkalnictwo wspomagane, domy pomocy społecznej, niepełnosprawność 